\title{
Adsorption of methylene blue from aqueous solutions by pyrolusite ore
}

\author{
N.Demirkıran*, G.D.Turhan Özdemir, M.Saraç, M.Dardağan \\ Department of Chemical Engineering, Faculty of Engineering, Inonu University, Malatya, 44280, Turkey. \\ *Corresponding author: nizamettin.demirkiran@inonu.edu.tr
}

Received: 09 August 2017; revised: 03 September 2017; accepted: 11 September 2017

\begin{abstract}
In this study, the adsorption of methylene blue dye was examined by using pyrolusite ore as a low-cost alternative adsorbent source. Pyrolusite, which contains mainly $\mathrm{MnO}_{2}$, is a manganese ore. The effects of the initial concentration of dye, contact time, initial $\mathrm{pH}$ of solution, adsorbent dosage, stirring speed of solution, and average particle size of adsorbent on the adsorption of methylene blue were studied. It was found that the percentage of the adsorbed dye increased with increasing the amount of pyrolusite. While the initial dye concentration, initial $\mathrm{pH}$, contact time, stirring speed, particle size, and adsorbent dosage were $25 \mathrm{ppm}, 6,90 \mathrm{~min}, 250 \mathrm{rpm}, 63 \mu \mathrm{m}$, and $12 \mathrm{~g} / \mathrm{l}$, respectively, the efficiency of dye adsorption on pyrolusite ore was $99 \%$. The isotherm and kinetic studies relating to this adsorption process were also made. It was found that the equilibrium data followed the Langmuir isotherm model while the kinetic of process could be described by the pseudo-second order kinetic model.
\end{abstract}

Keywords: Adsorption, low cost adsorbent, methylene blue, pyrolusite ore

\section{INTRODUCTION}

The waste solutions containing organic and/or inorganic contaminants after various industrial processing come into existence. These effluents are frequently discharged directly to environment. Discharged wastewaters can induce serious damages on the environment and human health due to their hazardous ingredients. Therefore, from both environmental and economical perspectives, organic and inorganic pollutions in industrial wastewater must be removed or reduced to the permissible levels before they are discharged to the environment by using appropriate separation methods [1-3].

Synthetic organic dyestuffs are widely used in order to color the products manufactured in textile, paper, rubber, plastics, leather, cosmetics, food, and pharmaceutical industries. In these industries, substantial amounts of water are used during process. Correspondingly, the wastewater emergent from these processes contain dyes at various ratios. The effluents containing dyes are mostly released directly to water source without applying any purification procedure. These kinds of wastewaters can cause to the pollution of water and soil in the surrounding of the plant due to their toxic, nondegradable, and carcinogenic characters. Consequently, human beings, and flora and fauna are negatively affected from this environmental pollution [4-7].

The methods applied for removal of dyes from wastewater adsorption [3, 12-15], membrane filtration [16, 17], and microbial degradation [18, 19] have been applied for treating the effluents containing dyes.
Among the methods mentioned above, adsorption process is one of the most widely used methods for elimination of dye from industrial waste solutions. Activated carbon obtained from various sources has been often used as adsorbent for the removal of dyes due to its high adsorption capacity [3, 12, 14, 15]. However, activated carbon is not economically feasible for large scale applications because of its high cost of production and regeneration. Hence, the use of the adsorbents having low cost can be advantageous for elimination of dyes from wastewater by adsorption process. The materials that have been used for this purpose include both natural materials and wastes, and byproducts generated from many industries. These materials are widely known as low-cost adsorbents. Among these alternative adsorbent sources, natural materials (ores or minerals) can be used for the removal of various species from wastewaters owing to its low-cost and abundance [2, 4, 20]. Methylene blue is one of the colored organic compounds, and it is mainly used for dying cotton, wool, and silk [2, 5]. For removal of methylene blue from wastewaters generated various industrial plants, active carbon manufactured different sources [2-4, 12, 21], saw dust [22], natural ores and their wastes [23-25], different clays $[26,27]$, biomass $[5,28]$, and agricultural solid wastes $[29,30]$ have been used as low-cost adsorbents.

Manganese is the twelfth most abundant element in the earth's crust. The most common mineral is pyrolusite, which is mainly $\mathrm{MnO}_{2}$. Low-grade pyrolusite ore in its natural state has little commercial value. For this reason, it is usually treated and converted into the metal or

(C) The Author(s). 2017 Open access This article is distributed under the terms of the Creative Commons Attribution 4.0 International License (http://creativecommons.org/licenses/by/4.0/), which permits unrestricted use, distribution, and reproduction in any medium, provided you give appropriate credit to the original author(s) and the source, provide a link to the Creative Commons license, and indicate if changes were made. 
other more valuable manganese compounds. This ore is essentially used for the production of manganese sulfate. This ore contains iron oxide, silica, and clay minerals in addition to manganese oxide depending on the ore source. These oxides and clay minerals existed in ore matrix have adsorbent feature, and they exhibit high potential for adsorption of various species. Hence, pyrolusite ore can use as a low-cost adsorbent in the adsorption process because of its abundant in the natural state, ease of availability, and direct use without pretreatment [31, 32].

The adsorptions of various inorganic and organic species using pyrolusite and manganese nodules have been examined by different researchers. Manganese ores supplied from different locations, manganese nodules, and leach residues of manganese ores have been utilized for elimination of various inorganic and organic species from aqueous solutions by adsorption process [23, 33-39].

The aim of this study is to investigate the use of pyrolusite as an alternative adsorbent material for the removal of methylene blue dye from aqueous solutions. The effects of the experimental parameters, including initial solution concentration and contact time, adsorbent dosage, initial solution $\mathrm{pH}$, stirring speed, and particle size on the adsorption of methylene blue dye from aqueous solutions have been studied.

\section{EXPERIMENTAL}

The pyrolusite ore sample used in this experimental study was provided from Konya, Turkey. The ore sample was crushed, ground, and then sieved using standard test sieves to obtain different particle size fractions. The original ore sample was analyzed, and it was determined that the mineral contained $57.66 \% \mathrm{MnO}_{2}, 10.00 \% \mathrm{CaO}$ $8.04 \% \mathrm{Fe}_{2} \mathrm{O}_{3}, 7.08 \% \mathrm{SiO}_{2}, 0.93 \% \mathrm{Al}_{2} \mathrm{O}_{3}, 0.44 \% \mathrm{MgO}$, $15.85 \%$ loss of ignition (at $800^{\circ} \mathrm{C}$ ). The mineralogical composition of the pyrolusite ore was determined by X-ray diffraction analysis using a Rigaku RadB-DMAX II model X-ray diffractometer. The X-ray diffraction pattern of the ore sample is shown in Figure 1.

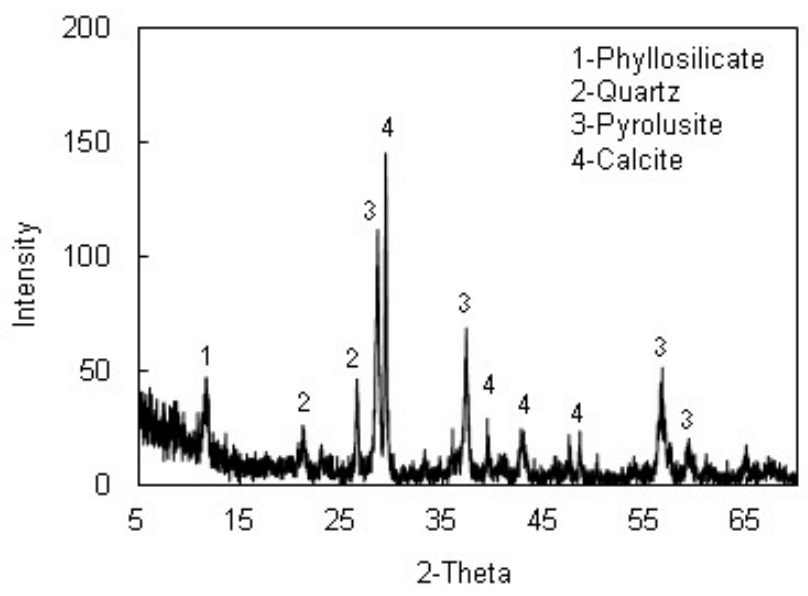

Fig. 1. X ray diffraction pattern of the ore sample used in the study

This figure indicates that the ore sample used is mainly composed of pyrolusite $\left(\mathrm{MnO}_{2}\right)$, phyllosilicate, quartz, and calcite.

All the chemicals (methylene blue, sodium hydroxide, sulfuric acid) used in the experiments were analytical grade and were employed as received without further purification. The stock solution was prepared by dissolving the required amount of methylene blue dye in distilled water. The test solutions used in the experiments were prepared by diluting stock solution to the desired concentrations.

The batch adsorption tests were performed in $100 \mathrm{ml}$ conical flasks placed on a magnetic stirrer. In each adsorption test, after a volume of $50 \mathrm{ml}$ dye solution at a definite concentration was placed into the glass flask, a given amount of pyrolusite was added to the dye solution. The initial $\mathrm{pH}$ of test solutions was adjusted using diluted $\mathrm{H}_{2} \mathrm{SO}_{4}$ or $\mathrm{NaOH}$. The $\mathrm{pH}$ values of the sample solutions were determined using WTW pMx2000 pH meter. All adsorption experiments were carried out at laboratory temperature. The adsorption process was performed for various contact times. The concentration of dye in the aqueous solution after adsorption tests was analyzed using UV spectrophotometer (Shimadzu UV-1800). The absorbances of methylene blue solutions having different concentrations were measured at various wavelengths, and maximum absorbance was determined at wavelength of $662 \mathrm{~nm}$. Thus, the absorbance of residual concentration of methylene blue after adsorption process was measured at wavelength of $662 \mathrm{~nm}$. The amount of dye adsorbed by pyrolusite ore was calculated from difference between the dye concentration before and after adsorption. The percentage of dye removal and the amount of dye adsorbed per unit mass of ore were evaluated by using the following equations, respectively.

$$
\begin{gathered}
\% \text { Removal }=\left(\frac{C_{i}-C_{t}}{C_{i}}\right) \times 100 \\
q_{e}=\frac{\left(C_{i}-C_{e}\right) V}{m}
\end{gathered}
$$

where:

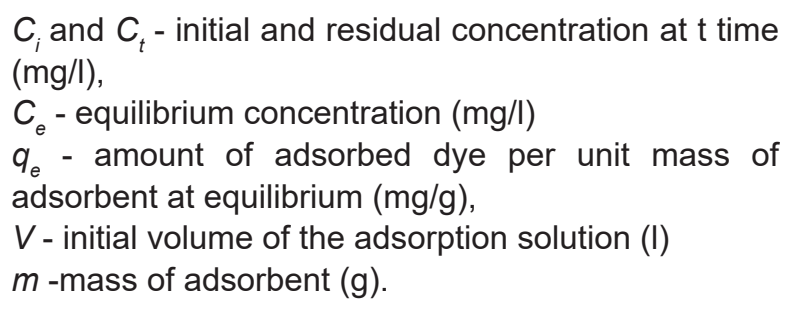

\section{RESULTS AND DISCUSSION}

Determination of optimal adsorbent dosage:

To determine the optimum adsorbent dosage for different concentrations of methylene blue, the experiments were performed at five different pyrolusite dosages in the range of $0.2-0.6 \mathrm{~g}$ while the initial concentrations of the solution containing methylene blue dye were changed from 10 to $150 \mathrm{ppm}$. While practicing these experiments, the values of the contact time, total volume of dye solution, particle size of pyrolusite, and agitation speed of solution were kept constant at $60 \mathrm{~min}, 50 \mathrm{ml}, 89.5 \mu \mathrm{m}$, 
and $250 \mathrm{rpm}$, respectively. In these tests, the initial $\mathrm{pH}$ of dye solutions was 6 . Figure 2 shows the effect of the adsorbent dosage on the adsorption of methylene blue at different initial concentrations.

As can be seen in Figure 2, the percentage of the adsorbed dye decreased for the same amount of pyrolusite as the initial concentration increased. In other words, the amount of the adsorbed dye increased for the same initial concentration of methylene blue when the amount of pyrolusite increased. For all initial dye concentrations, the maximum dye removal occurred at $0.6 \mathrm{~g}$ adsorbent dosage. After $60 \mathrm{~min}$ adsorption time, the extent of removal of dye from the solution at the amount of adsorbent dosage of $0.6 \mathrm{~g}$ was $94 \%, 91 \%$, $88 \%, 71 \%, 59 \%$, and $35 \%$, at $10,25,50,75,100$, and $150 \mathrm{ppm}$ of concentration, respectively.

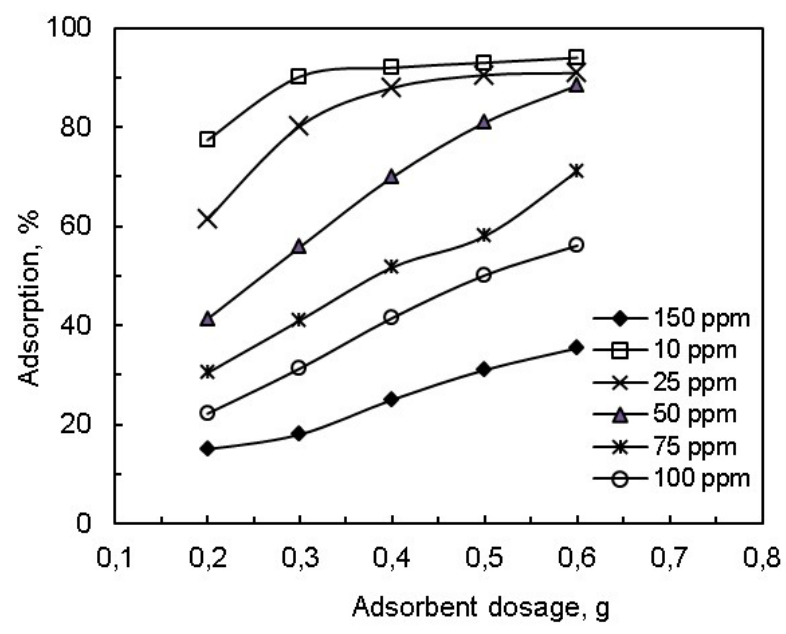

Fig.2. Effect of adsorbent dosage on different dye concentrations

An increase the adsorbent dosage for a given initial dye concentration or a decrease the adsorbate concentration for a defined adsorbent dosage can provide a greater surface area or adsorption sites between adsorbent and dye molecules. Thus, the extent of methylene blue adsorption increases.

\section{Effect of particle size of pyrolusite on adsorption:}

The adsorption extent is proportional to the surface area of the solid adsorbent because the adsorption is a surface event. Therefore, more finely divided solid can provide more surface area per unit weight of a solid adsorbent. Hence, the effect of particle size of pyrolusite on adsorption process was studied using the average size fractions of $115,89.5,68.5$, and $63 \mu \mathrm{m}$. In these tests, the values of the initial concentration of dye solution, total volume, initial $\mathrm{pH}$, adsorbent dosage, contact time, and stirring speed were chosen to be 50 ppm, $50 \mathrm{ml}, 6,0.6 \mathrm{~g}, 60 \mathrm{~min}$, and $250 \mathrm{rpm}$, respectively. The results obtained from these experiments are shown in Figure 3. As can be seen Figure 3, the percentage of the adsorbed methylene blue increased with a decrease in particle size of pyrolusite.

\section{Effect of initial $\mathrm{pH}$ of solution on adsorption:}

The effect of the initial $\mathrm{pH}$ of dye solution on adsorption process was investigated at the $\mathrm{pH}$ of $3,4,5$, and 6 . In

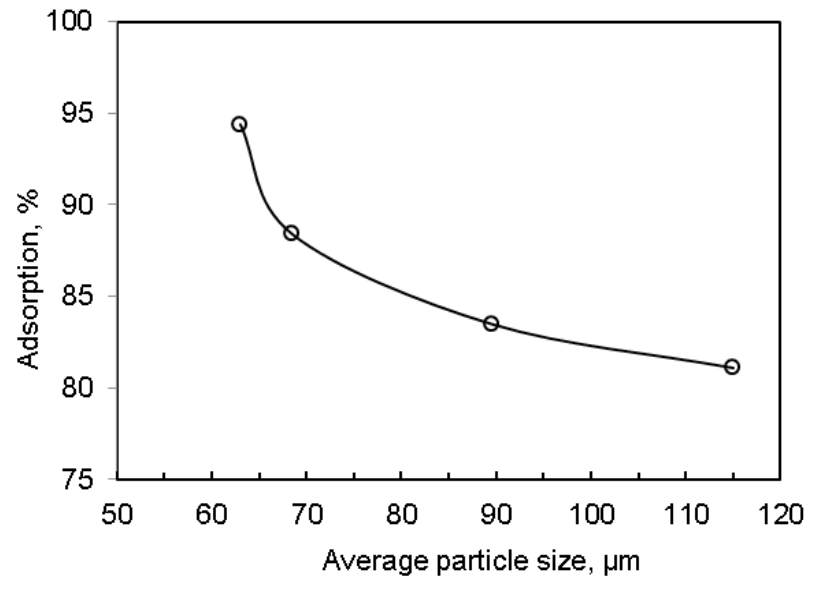

Fig.3. Effect of average particle size on dye adsorption

these tests, the initial concentration of dye solution, total volume, stirring speed, particle size, contact time, and adsorbent dosage were fixed at $50 \mathrm{ppm}, 50 \mathrm{ml}$, $250 \mathrm{rpm}, 63 \mu \mathrm{m}, 60 \mathrm{~min}$, and $0.6 \mathrm{~g}$, respectively. The results obtained from these experiments were given in Figure 4. It can be seen from this figure that the extent of methylene blue adsorption increased with increasing the initial $\mathrm{pH}$. Methylene blue is a cationic dye. Therefore, adsorption of methylene blue increases because electrostatic interaction can improve between absorbent and dye molecules with increasing $\mathrm{pH}$ of solution.

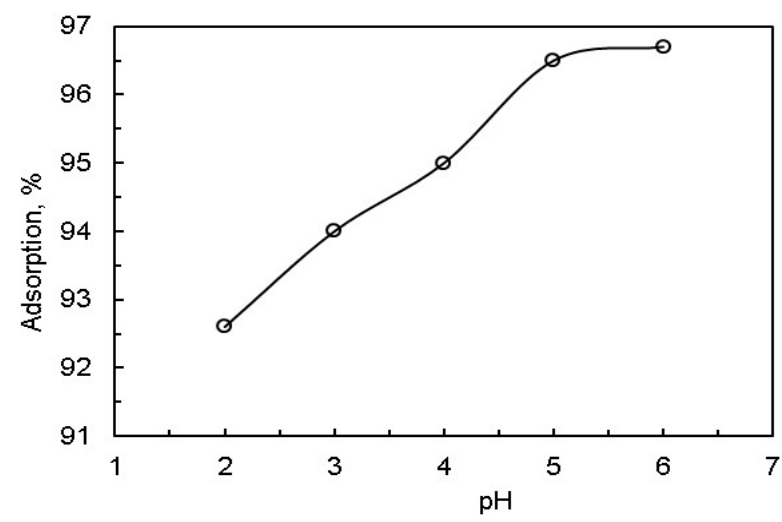

Fig.4. Effect of initial pH of solution on dye adsorption

\section{Effect of stirring speed on adsorption:}

Experiments were carried out at stirring speeds of 150 , 200,250 , and $300 \mathrm{rpm}$ to observe the effect of the stirring speed on adsorption of methylene blue by pyrolusite ore. In these experiments, the initial concentration of dye solution, total volume, particle size, contact time, adsorbent dosage, and initial $\mathrm{pH}$ of solution were selected to be 50 ppm, $50 \mathrm{ml}, 63 \mu \mathrm{m}, 60 \mathrm{~min}, 0.6 \mathrm{~g}$, and 6 , respectively.

Figure 5 shows the experimental results concerning the effect of stirring speed on adsorption of methylene blue. These results show that the amount of adsorbed dye increases with increasing stirring speed.

\section{Effect of contact time on adsorption:}

The effect of contact time on adsorption process was examined in the range 0-180 min for different concentrations $(25,50,75$, and $100 \mathrm{ppm})$ of methylene 
blue. In these tests, the values of volume of sample solution, particle size, adsorbent dosage, and initial $\mathrm{pH}$ of solution were kept constant at $50 \mathrm{ml}, 63 \mu \mathrm{m}, 0.6 \mathrm{~g}$, and 6 , respectively.

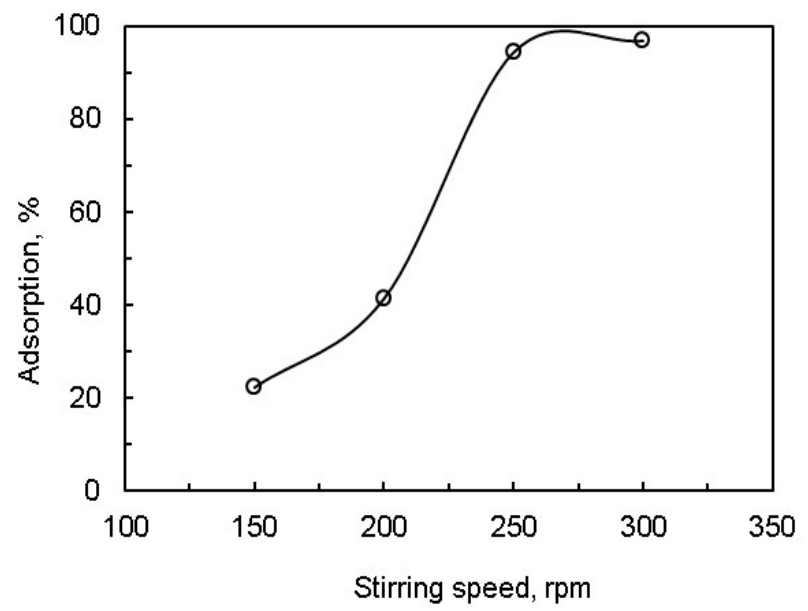

Fig.5. Effect of stirring speed on dye adsorption

The results obtained from these experiments are given in Figure 6. It can be said from observed results that adsorption of methylene blue by pyrolusite is considerably fast in the first 20 min, and afterwards the adsorption of dye occurs gradually and reaches the equilibrium at about $60 \mathrm{~min}$. It can be attributed to that there is considerable vacant surface sites for initial stage of process.

In adsorption process, the equilibrium between the adsorbent and adsorbate is described by adsorption isotherms. The isotherms indicate the relation between the equilibrium concentration in the solid phase and in the aqueous phase for the adsorbate molecules when the process reaches an equilibrium state. Various adsorption isotherms have been developed to realize the interaction between the adsorbed molecules and the solid adsorbent. Among these isotherm models, the Freundlich and Langmuir models are the most widely applied isotherms for various adsorption processes [5, 14]. In this study, these two isotherm models were applied to analyze the adsorption data obtained from the experiments.

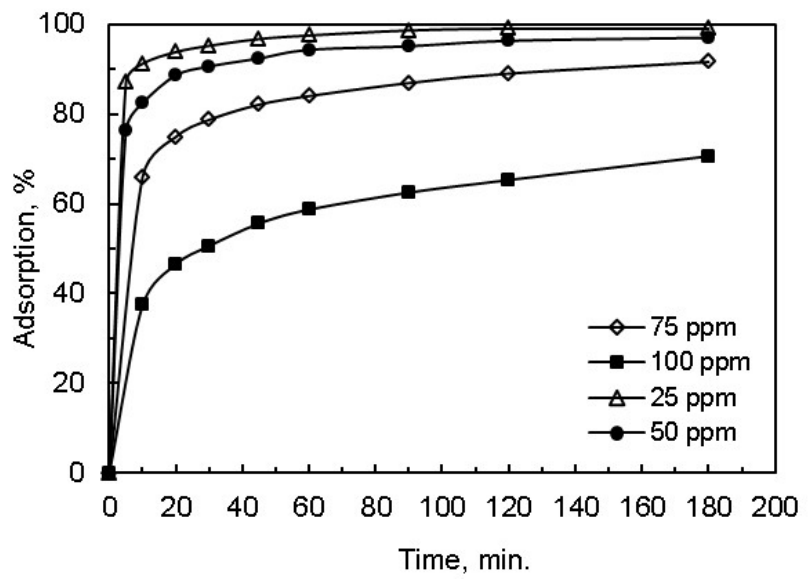

Fig. 6. Effect of initial concentration on dye adsorption for various contact times.
The Freundlich model assumes that the adsorption occurs on the heterogeneous surface of the solid adsorbent. On the other hand, the Langmuir model supposes that the adsorption takes place on a homogeneous surface by monolayer sorption without interaction between adsorbed molecules [5, 14]. The linear forms of the Freundlich and Langmuir isotherm equations are given as follows:

(for the Freundlich model)

$$
\log q_{e}=\log K_{f}+\frac{1}{n} \log C_{e}
$$

(for the Langmuir model)

$$
\frac{C_{e}}{q_{e}}=\frac{1}{q_{\max } K_{L}}+\frac{C_{e}}{q_{\max }}
$$

where:

$q_{e}$ - amount of adsorbate adsorbed per unit mass of adsorbent $(\mathrm{mg} / \mathrm{g})$,

$C_{e}$ - equilibrium concentration of the adsorbate $(\mathrm{mg} / \mathrm{l})$,

$K_{f}$ and $\mathrm{n}$ - are the Freundlich constants, including the adsorption capacity of the adsorbent $(\mathrm{mg} / \mathrm{g})(\mathrm{l} / \mathrm{g})^{1 / \mathrm{n}}$ and the adsorption intensity of adsorbent, respectively,

$q_{\max }$ - monolayer adsorption capacity of the adsorbent (mg/g),

$K_{L}$ - Langmuir constant $(\mathrm{I} / \mathrm{g})$.

If the adsorption process obeys the Freundlich model, then the left side $\left(\log q_{e}\right)$ of $\mathrm{Eq}$. (3) versus $\log C_{e}$ must be straight line. On the other hand, if the adsorption process obeys the Langmuir model, then the left side $\left(C_{e} / q_{e}\right)$ of Eq. (4) versus $C_{e}$ must be straight line. When the experimental data obtained were plotted for the Freundlich model, straight line with low correlation coefficient was observed. Therefore, it can be said that the Freundlich model was inappropriate for this study. The adsorption data were then analyzed by using the Langmuir model. When the graph of the left side $\left(C_{e} /\right.$ $q_{e}$ ) of Eq. (4) versus $C_{e}$ was drawn using the adsorption data, straight line with high correlation coefficient was found. Figure 7 represents the lot of $C_{e} / q_{e}$ versus $C_{e}$ for

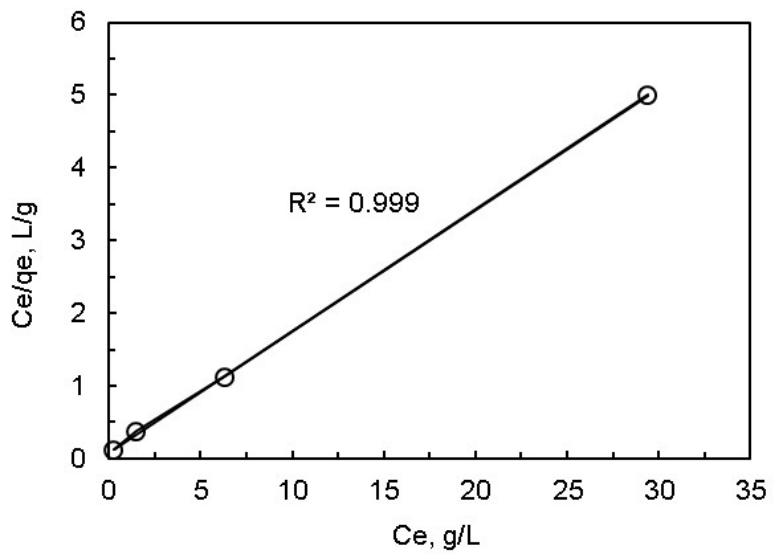

Fig. 7. The Langmuir isotherm plot for dye adsorption on pyrolusite ore. 
various concentrations.

In Eq. (4), the slope of the straight line give $1 / q_{\max }$, and the intercepts give $1 / q_{\max } K_{L}$. The values of $q_{\max }$ and $K$ parameters were calculated as 5.992 , and 1.838 , respectively. Therefore, it can be said that this adsorption process obeys the Langmuir model. The main properties of the Langmuir isotherm can be described by a dimensionless constant called equilibrium parameter or separation factor [21]. This is expressed as follows:

$$
R_{L}=\frac{1}{1+K_{L} C_{0}}
$$

where:

$R_{L}$ - dimensionless constant called separation factor or equilibrium parameter

$K_{L}$ - Langmuir constant (I/mg),

$C_{0}$ - initial concentration of solution $(\mathrm{mg} / \mathrm{l})$

The values of $R_{L}$ indicate the nature of the adsorption process. A value of $R_{L}$ in the range from 0 to 1 indicates that the adsorption process between the adsorbent and adsorbate is favorable under the experimental conditions performed. This also indicates that the Langmuir isotherm is valid for adsorption process. The values of $R_{L}$ were found to be $0.0213,0.0107,0.0072$ and 0.0054 at concentrations of 25, 50, 75 and $100 \mathrm{ppm}$, respectively. All the findings mentioned above show that the adsorption of methylene blue dye by pyrolusite ore follows the Langmuir isotherm model.

The kinetic analysis of the adsorption processes is generally performed using pseudo-first order and pseudo-second order kinetic models. The equations describing these kinetics models are as follows:

(for the pseudo-first order kinetic)

$$
\ln \left(q_{e}-q_{t}\right)=\ln q_{e}-k_{1} t
$$

(for the pseudo-second order kinetic)

$$
\frac{t}{q_{t}}=\frac{1}{k_{2} q_{e}^{2}}+\frac{1}{q_{e}} t
$$

where:

$q_{e}$ - amount of the adsorbed metal ion at equilibrium $(\mathrm{mg} / \mathrm{g})$

$q_{t}$ - amount of the adsorbed metal ion at t time $(\mathrm{mg} / \mathrm{g})$

$k_{1}$ - rate constant for the first order adsorption ( $\left.1 / \mathrm{min}\right)$

$k_{2}$ - rate constant for the second order adsorption

(g/mg.min)

$\mathrm{t}$ - adsorption time (min)

To determine the kinetic model of the adsorption between pyrolusite ore and dye, the plot of $\ln \left(q_{e}-q_{t}\right)$ versus $t$ for the pseudo-first order kinetic was drawn using the experimental data obtained. For the pseudo-second order kinetic, the plot of the left side of Eq. (7), t/qe, versus $t$ was constructed. It was observed that the low correlation coefficients were obtained for the pseudofirst order kinetic model. Figure 8 shows the graph

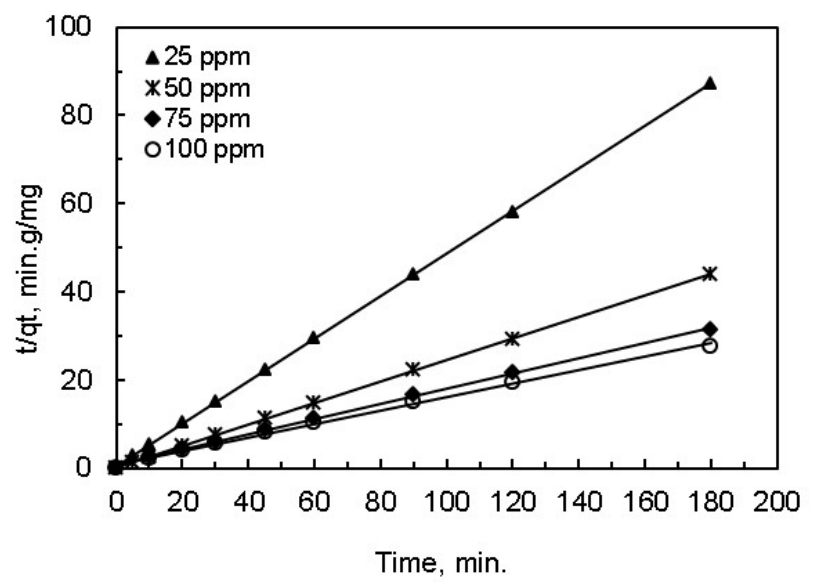

Fig. 8. The pseudo-second order kinetic plot for dye adsorption.

constructed for pseudo-second order kinetic model. The slopes of the straight lines in Figure 8 are 1/qe, and the intercepts are $1 / k_{2} q_{e}{ }^{2}$ for the pseudo-second order kinetic The values of the rate constants and correlation coefficients determined from Figure 8 are given in Table 1 .

\begin{tabular}{|c|c|c|c|c|}
\hline \multirow{2}{*}{$\begin{array}{l}\text { Initial } \\
\text { concent- } \\
\text { ration } \\
(p p m)\end{array}$} & \multirow{2}{*}{$\begin{array}{c}\text { Experimental } \\
\qquad q_{e} \\
(\mathrm{mg} / \mathrm{g})\end{array}$} & \multicolumn{3}{|c|}{ Pseudo-Second Order Kinetic } \\
\hline & & $\begin{array}{c}\text { Calculated } \\
q_{\mathrm{e}} \\
(\mathrm{mg} / \mathrm{g})\end{array}$ & $\begin{array}{c}\mathbf{k}_{2} \\
\text { (g/mg.min) }\end{array}$ & $\mathbf{R}^{2}$ \\
\hline 25 & 2.063 & 2.072 & 0.5463 & 0.999 \\
\hline 50 & 4.042 & 4.115 & 0.3066 & 0.999 \\
\hline 75 & 5.625 & 5.787 & 0.0403 & 0.998 \\
\hline 100 & 5.883 & 6.557 & 0.0258 & 0.997 \\
\hline
\end{tabular}

Table 1. Kinetic parameters for the adsorption of methylene blue by pyrolusite ore.

In addition, it can be seen in Table 1 that the $q_{e}$ values calculated from the intercepts of the straight lines in Figure 8 are good agreement with the $q_{e}$ values determined experimentally. The values of the correlation coefficients and the agreement between the $q_{e}$ values indicate that this adsorption process follows the pseudosecond order kinetics.

\section{CONCLUSIONS}

In this study, pyrolusite ore has been used as an alternative adsorbent for the removal of methylene blue dye from aqueous solutions. The effects of the initial concentration of solution, adsorbent dosage, particle size of adsorbent, stirring speed of solution, and initial $\mathrm{pH}$ of solution on dye adsorption were investigated. It was determined that the percentage of the adsorbed dye increased with increasing the pyrolusite dosage, stirring speed and initial $\mathrm{pH}$, and with decreasing the average particle size of adsorbent and initial concentration of dye. Depending on the experimental conditions, it was observed that methylene blue was removed at high rates from aqueous solution. The isotherm and kinetic analysis showed that the equilibrium data followed the Langmuir isotherm model while the process kinetic obeyed the pseudo-second order kinetic 
model. According to findings obtained, it can be said that the methylene blue adsorption process by pyrolusite ore occurs by chemisorption.

The present work suggests that the pyrolusite ore can be utilized as a relatively low-cost adsorbent for the removal of dye from wastewaters because the ore is available in its natural state without any need for a preliminary process.

\section{REFERENCES}

1. Deliyanni E.A., Lazaridis N.K., Peleka E.N., Matis, K.A. (2004) Metal removal from aqueous solution by iron-based bonding agents. Environ. Sci. Pollut. Res., 11, 18-21.

2. Rafatullah M., Sulaiman O., Hashim R., Ahmad, A. (2010) Adsorption of methylene blue on low cost adsorbent: A review. J. Hazard. Mater., 177, 70-80.

3. Y.C., Uma and Upadhyay, S.N. (2011) An economically viable removal of methylene blue by adsorption on activated carbon prepared from rice husk. Can. J. Chem. Eng., 89, 377-383.

4. Crini G. (2006) Non-conventional low-cost adsorbent for dye removal: A review. Bioresour. Technol., 97, 1061-1085.

5. Hameed B.H., Ahmad A.A. (2009) Batch adsorption of methylene blue from aqueous solution by garlic peel, an agricultural waste biomass. J. Hazard. Mater., 164, 820-875.

6. Tang Z., Liu C., Chen Y., Jiang L., Ji X., Jiang, W. (2010) Batch and fixed-bed adsorption of actual dyeing wastewater on sludge-based adsorbent from pyrolusite-catalyzed pyrolysis. Fresenius Environ. Bull., 19, 3000-3006.

7. Shi H., Li W., Zhong L., Xu, C. (2014) Methylene blue adsorption from aqueous solution by magnetic cellulose/graphene oxide composite: Equilibrium, kinetics, and thermodynamics. Ind. Eng. Chem. Res., 53, 1108-1118.

8. Mohan S.V., Sailaja P., Srimurali M., Karthikeyan J. (1999) Color removal of monoazo acid dye from aqueous solution by adsorption and chemical coagulation. Environ. Eng. Policy, 1, 149-154.

9. El Gohary F., Tawfik, A. (2009) Decolorization and COD reduction of disperse and reactive dyes wastewater using chemical-coagulation followed by sequential batch reactor (SBR) process. Desalination, 249, 1159-1164.

10. Seculaa M.S., Cagnonb B., De Oliveirac T.F., ChedevillebO.,FauduetH.(2012)Removalofaciddye from aqueous solutions by electrocoagulation/GAC adsorption coupling: Kinetics and electrical operating costs. J. Taiwan Inst. Chem. Eng., 43, 767-775.

11. Mkpenie V.N., Abakedi O.U. (2015) Electrocoagulation of azo-2-naphthol dye using aluminium electrodes: effect of solvent and kinetics of adsorption. Current Res. Chem., 7, 34-43.

12. Kannan N., Sundaram M.M. (2001) Kinetics and mechanism of removal of methylene blue by adsorption on various carbons-A comparative study. Dyes and Pigments, 51, 25-40.
13. Zhu M.X., Lee I., Wang H.H., Wang, Z. (2007) Removal of an anionic dye by adsorption/ precipitation processes using alkaline white mud. J. Hazard. Mater., 149, 735-741.

14. Tan I.A.W., Hameed B.H., Ahmad, A.L. (2007) Equilibrium and kinetics studies on basic dye adsorption by oil palm fibred activated carbon. Chem. Eng. J., 127, 111-119.

15. Demirbaş E. Kobya M., Sulak M.T. (2008) Adsorption kinetics of a basic dye from aqueous solutions onto apricot stone activated carbon. Bioresour. Technol., 99, 5368-5373.

16. Abid M.F., Zablouk M.A., Abid-Alameer, A.M. (2012) Experimental study of dye removal from industrial wastewater by membrane technologies of reverse osmosis and nanofiltration. Iranian J. Environ. Health Sci. Eng., 9, 17-25.

17. Zhua X., Zhenga Y., Chena Z., Chena Q., Gaoa B., Yu S. (2013) Removal of reactive dye from textile effluent through submerged filtration using hollow fiber composite nano filtration membrane. Desalination Water Treat., 51, 31-33.

18. Buthelezi S.P., Olaniran A.O., Pillay B. (2012) Textile dye removal from wastewater effluents using bioflocculants produced by indigenous bacterial isolates. Molecules, 17, 14260-14274.

19. Shah M.P., Patel K.A., Nair S.S., Darji A.M. (2013). Microbial degradation of textile dye (Remazol Black B) by Bacillus spp. ETL-2012. J. Bioremed. Biodeg., 4, 1-5.

20. Gupta V.K., Carrott P.J.M., Ribeiro Carrott, M.M.L., Suhas. (2009) Low-cost adsorbents: growing approach to wastewater treatment-a review. Critic. Rev. Environ. Sci. Technol., 39, 783-842.

21. Kavitha D., Namasivayam C. (2007) Experimental and kinetic studies on methylene blue adsorption by coir pith carbon. Bioresour. Technol., 98, 14-21.

22. Bello O.S., Adelaide O.M., Hammed M.A., Popoola, O.A.M. (2010) Kinetic and equilibrium studies of methylene blue removal from aqueous solution by adsorption on treated sawdust. Maced. J. Chem. Chem. Eng., 29, 77-85.

23. Shaoo R.N., Das S.C., Reddy B.R, Rath P.C., Das R.P. (2001) Adsorption of copper on manganese nodule residue obtained from NH3-SO2 leaching. Hydrometallurgy, 62, 185-192.

24. Gupta V.K., Ali I., Saini V.K. (2004) Removal of rhodamine $b$, fast green, and methylene blue from wastewater using red mud, an aluminum industry waste. Ind. Eng. Chem. Res., 43, 1740-1747.

25. Kuan W.H., Chen C.Y., Hu C.Y. (2011) Removal of methylene blue from water by $\mathrm{Y}-\mathrm{MnO}$. Water Sci. Technol., 64, 899-903.

26. Hajjaji M., Alami A., El Bouadili A. (2006) Removal of methylene blue from aqueous solution by fibrous clay minerals. J. Hazard. Mater., B135, 188-192.

27. Hong S., Wen C., He J., Gan F., Ho Y.S. (2009) Adsorption thermodynamics of methylene blue onto bentonite. J. Hazard. Mater., 167, 630-633.

28. Dey M.D., Shukla R., Bordoloi N.K., Doley R., 
Mukhopadhyay R. (2015) Mechanism of adsorptive removal of methylene blue using dried biomass of rhizopus oryzae. Appl. Biochem. Biotechnol., 177, 541-555.

29. Ofomaja A.E. (2009) Equilibrium sorption of methylene blue using mansonia wood sawdust as biosorbents. Desalination Water Treat., 3, 1-10.

30. Lazima Z.M., Mazuina E., Hadibarataa T., Yusop Z. (2015) The removal of methylene blue and remazol brilliant blue $\mathrm{R}$ dyes by using orange peel and spent tea leaves. Jurnal Teknologi, 74, 129-135.

31. Zhang W., Cheng C.Y. (2007) Manganese metallurgy review. Part I: Leaching of ores/secondary materials and recovery of electrolytic/chemical manganese dioxide. Hydrometallurgy, 89, 137-159.

32. Nayl A.A., Ismail I.M., Aly H.F. (2011) Recovery of pure MnSO4. $\mathrm{H} 2 \mathrm{O}$ by reductive leaching of manganese from pyrolusite ore by sulfuric acid and hydrogen peroxide. Int. J. Miner. Process., 100, 116123.

33. Ajmal M., Rao R.A.K., Siddiqui B.A. (1995) Adsorption studies and the removal of dissolved metals using pyrolusite as adsorbent. Environ. Monitor. Assess., 38, 25-35.
34. Bernard S., Chazal P.H., Mazet M. (1997) Removal of organic compounds by adsorption on pyrolusite (ß-MnO2). Water Res., 13, 1216-1222.

35. Chakravarty S., Dureja V., Bhattacharyya G., Maity S., Bhattacharjee S. (2002) Removal of arsenic from groundwater using low cost ferruginous manganese ore. Water Res., 36, 625-632.

36. Rout K., Mohapatra M., Mohapatra B.K., Anand S. (2009) $\mathrm{Pb}(\mathrm{II}), \mathrm{Cd}(\mathrm{II})$ and $\mathrm{Zn}(\mathrm{II})$ adsorption on low grade manganese ore. Int. J. Eng. Sci. Technol., 1, 106-122.

37. Liu C., Wang X., Li X., Cao W., Yang J. (2012) Detoxification of arsenite through adsorption and oxidative transformation on pyrolusite. Clean-Soil Air Water, 40, 1265-1272.

38. Shen W., Liao B., Sun W., Su S., Ding S. (2014) Adsorption of Congo red from aqueous solution onto pyrolusite reductive leaching residue. Desalination Water Treat., 52, 3564-3571.

39. Demirkıran N. (2015) Copper adsorption by natural manganese dioxide. Trans. Nonferrous Met. Soc. China, 25, 647-653. 